\title{
DNA Relatedness among Some Thermophilic Members of the Genus Methanobacterium: Emendation of the Species Methanobacterium thermoautotrophicum and Rejection of Methanobacterium thermoformicicum as a Synonym of Methanobacterium thermoautotrophicum
}

\author{
JEAN PIERRE TOUZEL, ${ }^{1 *}$ EVERLY CONWAY DE MACARIO, ${ }^{2}$ JÖRK NÖLLING, ${ }^{3}$ \\ WILLEM M. DE VOS, ${ }^{3}$ TATJANA ZHILINA, ${ }^{4}$ AND A. M. LYSENKO ${ }^{4}$
}

Institut National de la Recherche Agronomique, Station de Technologie Alimentaire, B.P. 39, F-59651 Villeneuve d'Ascq Cedex, France; ; Wadsworth Center for Laboratories and Research, New York State Department of Health, and Department of Biomedical Sciences, School of Public Health, State University of New York, Albany, New York 12201-0509²; Bacterial Genetics Group, Department of Microbiology, Agricultural University of Wageningen, NL-6703 CT Wageningen, The Netherlands ${ }^{3}$; and Institute of Microbiology, Russian Academy of Sciences, Prospect 60-Let Oktyabrya, 7/2, Moscow 117811, Russia

\begin{abstract}
DNA reassociation was used to determine levels of relatedness among four thermophilic Methanobacterium strains that are able to use formate and between these organisms and two representative strains of Methanobacterium thermoautotrophicum, strain $\Delta H^{T}\left(=D S M 1053^{T}=A T C C 29096{ }^{T}\right)(T=$ type strain) and strain Marburg (= DSM 2133). Three homology groups were delineated, and these groups coincided with the clusters identified by antigenic fingerprinting. The first group, which had levels of cross hybridization that ranged from 73 to $99 \%$, included $M$. thermoautotrophicum $\Delta \mathbf{H}^{\mathbf{T}}$, Methanobacterium thermoformicicum Z-245, Methanobacterium sp. strain THF, and Methanobacterium sp. strain FTF. The second and third groups were each represented by only one strain, Methanobacterium sp. strain CB-12 and $M$. thermoautotrophicum Marburg, respectively (cross-hybridization levels, 13 to 30 and 29 to 33\%, respectively). Our results indicate that the name $M$. thermoformicicum should be rejected as it is a synonym of $M$. thermoautotrophicum. The taxonomic positions of strains Marburg and CB-12 need further investigation.
\end{abstract}

Rod-shaped, thermophilic, formate-utilizing, methane bacteria have been isolated from globally dispersed geographical locations. On the basis of differences of 10 to $15^{\circ} \mathrm{C}$ in temperature optima and temperature ranges compared with Methanobacterium thermoautotrophicum, a characteristic that has been used previously to separate species in the genera Methanogenium and Methanococcus, and on the basis of formate utilization, Zhilina and Ilarionov $(24,25)$ proposed the name Methanobacterium thermoformicicum for their isolate Z-245. This name has been validated (8a). However, the taxonomic position of this organism has never been clearly assessed. The purpose of this work was to use DNA-DNA hybridization for taxonomic assignment of four thermophilic formate-utilizing strains of the genus Methanobacterium, including isolate Z-245, which had been grouped previously by antigenic fingerprinting.

\section{MATERIALS AND METHODS}

Strains, media, and culture conditions. The strains used in this study are listed in Table 1. Most of these organisms were obtained from the Deutsche Sammlung von Mikroorganismen, Braunschweig, Germany; strains CB-12 and THF were kindly provided by David Boone and Steve Zinder, respectively. The methanogens were cultivated on BCYT medium as previously described (19). The medium was buffered with $50 \mathrm{mM}$ HEPES ( $N$-2-hydroxyethylpiperazine- $N^{\prime}$-2-ethane-

\footnotetext{
* Corresponding author.
}

sulfonic acid) or PIPES [piperazine- $N, N^{\prime}$-bis(2-ethanesulfonic acid)] unless otherwise indicated.

The anaerobic gas was an $\mathrm{H}_{2}-\mathrm{CO}_{2}$ mixture (80:20). Sterile media were inoculated with previous cultures $(2 \%, \mathrm{vol} / \mathrm{vol})$. Organisms were mass cultured in 2-liter fermentors containing the same media with continuous sparging of $\mathrm{H}_{2}-\mathrm{CO}_{2}$ and $\mathrm{H}_{2} \mathrm{~S}$.

G+C contents of the DNAs. Frozen cells were thawed and disrupted with a French press at $76,000 \mathrm{kPa}$, and the DNA was then purified by phenol extraction and hydroxylapatite adsorption as described by Johnson (9). The thermal denaturation procedure was used to determine the DNA guanineplus-cytosine $(\mathrm{G}+\mathrm{C})$ content. The DNA was dissolved in a saline citrate solution $(0.15 \mathrm{M} \mathrm{NaCl}$ plus $0.015 \mathrm{M}$ trisodium citrate 2-hydrate; $\mathrm{pH}$ brought to 7 with $0.1 \mathrm{~N} \mathrm{HCl}$ ). The $A_{260}$ and the cell temperature were digitally recorded at $0.5-\mathrm{min}$ intervals with a model SP 800 spectrophotometer (Kontron, Zürich, Switzerland) equipped with a model PD 415 temperature programmer (Huber, Offenburg-Elgersweier, Germany). The melting temperature was computed by using the method of the median as described by Ferragut and Leclerc (7).

DNA homologies. All of the DNA samples were sonicated at $0^{\circ} \mathrm{C}$ for $1 \mathrm{~min}$ with a Labsonic 1510 instrument (Braun, Melsungen, Germany) by using a $10-\mathrm{W}$ energy setting and a 4-mm probe. Sonication was performed a total of four times (1 min each), with 1-min rests between the sonic treatments.

Nick translation was performed with a Bethesda Research Laboratories kit by using the manufacturer's protocol and deoxy $\left[1^{\prime}, 2^{\prime}, 5^{\prime}-{ }^{3} \mathrm{H}\right]$ cytidine $5^{\prime}$-triphosphate as the radioac- 
TABLE 1. Sources of strains

\begin{tabular}{lclr}
\hline \multicolumn{1}{c}{ Strain } & Other designation & \multicolumn{1}{c}{ Geographical area } \\
\hline M. thermoautotrophicum $\Delta$ H $^{\mathrm{T}}$ & DSM $1053^{\mathrm{T}}$ & Urbana, Ill. & 22 \\
M. thermoautotrophicum Marburg & DSM 2133 & Marburg, Germany & 8 \\
M. thermoformicicum Z-245 & DSM 3720 & USSR & 24 \\
Methanobacterium sp. strain CB-12 & DSM 3664 & Chengdu, People's Republic of China \\
Methanobacterium sp. strain THF & DSM 3848 & Ithaca, N.Y. & 23 \\
Methanobacterium sp. strain FTF & DSM 3012 & Lille, France & 26 \\
\hline
\end{tabular}

tive label. After nick translation, the labeled DNA was separated from excess nucleotides by chromatography on Sephadex G-50 on a spun column as described by Maniatis et al. (13). The S1 nuclease-resistant cores in the radioactive probes were eliminated by chromatography on a hydroxyapatite column in a Pasteur pipette (bed dimensions, 0.6 by $5 \mathrm{~cm}$ ). The DNA sample was denaturated by heating it for 10 min in a boiling bath. The phosphate concentration was brought to about $0.1 \mathrm{M}$, and the sample was deposited on the top of the column. Fractions ( 5 drops) that were eluted by phosphate buffer $(0.12 \mathrm{M}, \mathrm{pH} 6.8)$ were monitored for radioactivity and pooled. The pooled fractions were freezedried and dissolved in $0.1 \mathrm{ml}$ of water. The phosphate buffer was replaced by TES (Tris-EDTA-saline) buffer by spuncolumn chromatography on Sephadex G-50.

The reassociation reaction mixtures contained $5 \mu l(0.010$ to $0.025 \mu \mathrm{g}, 6,000$ to $12,000 \mathrm{cpm})$ of labeled DNA, $100 \mu \mathrm{l}(40$ $\mu \mathrm{g})$ of unlabeled DNA, $35 \mu \mathrm{l}$ of water, and $280 \mu \mathrm{l}$ of a buffer containing $600 \mathrm{mM} \mathrm{NaCl}, 15 \mathrm{mM}$ EDTA (pH 8), $15 \mathrm{mM}$ Tris buffer ( $\mathrm{pH} 8$ ), $0.0225 \%$ sodium dodecyl sulfate, and $75 \%$ formamide. The DNA mixtures were denatured by heating them in boiling water for $10 \mathrm{~min}$. Hybridizations were conducted for $18 \mathrm{~h}$ at $35^{\circ} \mathrm{C}$. The single-stranded DNAs were eliminated by incubating the preparations for $1 \mathrm{~h}$ at $30^{\circ} \mathrm{C}$ in the presence of a suitable dilution of S1 nuclease (9), and the hybrids were precipitated with an equal volume of $10 \%$ trichloroacetic acid, collected on Whatman type GF/F fiberglass discs, washed five times with ice-cold trichloroacetic acid and then with ethanol, dried, and counted with a Betamatic liquid scintillation counter (Kontron) in the presence of $10 \mathrm{ml}$ of Insta-gel scintillation mixture.

DNA hybrid thermal stability. The thermal stabilities of the DNA-DNA hybrids were estimated by using the $S 1$ nuclease procedure described by Johnson (9). The temperatures used to obtain the dissociation profiles were 65 through $100^{\circ} \mathrm{C}$.

Antigenic fingerprinting. Antibody S-probes were prepared as previously described (11) from antisera against the reference methanogens listed in Table 4. Antigenic fingerprinting was done as described previously (10) by using indirect immunofluorescence and the quantitative slide immunoenzymatic assay (12). Levels of antigenic relatedness

TABLE 2. Reassociation of DNA from M. thermoautotrophicum $\Delta \mathbf{H}^{\mathrm{T}}$

\begin{tabular}{|c|c|c|c|}
\hline \multirow{2}{*}{$\begin{array}{c}\text { Source of unlabeled } \\
\text { DNA }\end{array}$} & \multicolumn{2}{|c|}{$\begin{array}{l}\% \text { Relative } \\
\text { binding at: }\end{array}$} & \multirow{2}{*}{$\begin{array}{c}\Delta T_{m} \text { at } \\
65^{\circ} \mathrm{C}\end{array}$} \\
\hline & $65^{\circ} \mathrm{C}$ & $75^{\circ} \mathrm{C}$ & \\
\hline M. thermoautotrophicum $\Delta \mathbf{H}^{\mathrm{T}}$ & 100 & 90 & 0 \\
\hline M. thermoformicicum Z-245 & 74 & 68 & 0.5 \\
\hline Methanobacterium sp. strain THF & 66 & 50 & 4.4 \\
\hline Methanobacterium sp. strain FTF & 74 & 72 & 0.7 \\
\hline
\end{tabular}

among the strains and between the strains and reference methanogens were determined by performing a comparative analysis of antigenic fingerprints with a reference table (12).

Nucleotide sequence accession numbers. The nucleotide sequences of $M$. thermoautotrophicum $\Delta \mathrm{H}^{\mathrm{T}}$ and $M$. thermoformicicum Z-245 5S rRNAs have been deposited in the EMBL Nucleotide Sequence Database under accession numbers X62857 and X62858, respectively.

\section{RESULTS AND DISCUSSION}

The $\mathrm{G}+\mathrm{C}$ contents of the six test strains (Table 3 ) ranged from 47 to $50 \mathrm{~mol} \%$. The values obtained for strains $\Delta \mathrm{H}^{\mathrm{T}}$ (T $=$ type strain) and Marburg (48.6 and $47.7 \mathrm{~mol} \%$, respectively) were in close agreement with the values obtained by Brandis et al. (4), who used the same method (48.6 and 47.6 mol\%, respectively). The previously reported values for the $\mathrm{G}+\mathrm{C}$ content of strain $\Delta \mathrm{H}^{\mathrm{T}}$ were 52 and $49.7 \mathrm{~mol} \%$ as determined by buoyant density in $\mathrm{CsCl}(1,22)$ and $49.4 \mathrm{~mol} \%$ as determined by thermal denaturation (14).

Levels of DNA homology were determined by using the DNA of each of the six strains as a reference. $\left[{ }^{3} \mathrm{H}\right] \mathrm{DNA}$ probes hybridized at levels of 71 to $82 \%$ with their homologous DNAs and at levels of 3 to $7 \%$ with unrelated DNA from salmon sperm. Table 3 shows that strains $\Delta H^{T}, Z-245$, FTF, and THF formed a homogeneous group with more than $73 \%$ homology. However, strain Marburg was noticeably distant from this group (level of homology, less than $35 \%$ ). Strain CB-12 exhibited less than $30 \%$ homology with strain Marburg and with each of the other strains.

The groups described above coincided with the clusters identified by antigenic fingerprinting. Table 4 shows that strains Z-245, FTF, and THF formed a cluster of related organisms that were close to reference strains $\Delta \mathrm{H}^{\mathrm{T}}$ and $\mathrm{GC1}$. On the other hand, strain CB-12 was antigenically less closely related to strains $\Delta \mathrm{H}^{\mathrm{T}}$ and $\mathrm{GCl}$, and strain Marburg was not related to either of these strains.

Strains $\Delta \mathrm{H}^{\mathrm{T}}, \mathrm{Z}-245, \mathrm{FTF}$, and THF clearly belong to the same species since they share more than $82 \%$ DNA homology. This conclusion is in agreement with the proposal of Priest et al. (18), who stated that, "Although there is no universally accepted level of DNA homology which delineates a bacterial species, most workers agree that strains within a species should share at least 50 to $60 \%$ homology." This grouping was further supported by the results of a $\Delta T_{m}$ study which showed that the most heterogeneous hybrid was the hybrid between strain $\Delta \mathrm{H}^{\mathrm{T}}$ and strain THF, which had a $\Delta T_{m}$ of less than $5^{\circ} \mathrm{C}$ (Table 2$)\left(\Delta T_{m}\right.$ is the difference between the melting temperature of a homologous hybrid and the melting temperature of a heterologous hybrid). Similar conclusions about the relationship between $M$. thermoautotrophicum $\Delta \mathrm{H}^{\mathrm{T}}$ and $M$. thermoformicicum $\mathrm{Z}-245$ were reached by Chumakov et al. (6) on the basis of data on $5 \mathrm{~S}$ RNA sequences, which differed in only six nucleotides (Fig. 
TABLE 3. Levels of DNA homology, melting temperatures, and $\mathrm{G}+\mathrm{C}$ contents

\begin{tabular}{|c|c|c|c|c|c|c|c|c|c|}
\hline \multirow{2}{*}{ Strain $^{a}$} & \multirow{2}{*}{$\begin{array}{c}\text { Formate } \\
\text { use }\end{array}$} & \multirow{2}{*}{$\begin{array}{c}\text { Melting } \\
\text { temp } \\
\left({ }^{\circ} \mathrm{C}\right)\end{array}$} & \multirow{2}{*}{$\begin{array}{l}\mathrm{G}+\mathrm{C} \\
\text { content } \\
(\mathrm{mol} \%)\end{array}$} & \multicolumn{6}{|c|}{$\%$ DNA homology with reference DNA from strain: } \\
\hline & & & & $\Delta \mathrm{H}^{\mathrm{T}}$ & Z-245 & THF & FTF & Marburg & CB-12 \\
\hline$\Delta \mathrm{H}^{\mathrm{T}}$ & - & 89.32 & $48.6 \pm 0.5$ & $100^{b}$ & 97 & 82 & 90 & 31 & 27 \\
\hline Z-245 & + & 89.39 & $48.8 \pm 0.3$ & 83 & 100 & 73 & 84 & 29 & 25 \\
\hline THF & + & 89.74 & $49.6 \pm 0.4$ & 88 & 77 & 100 & 74 & 30 & 23 \\
\hline FTF & + & 89.58 & $49.2 \pm 0.3$ & 99 & 100 & 82 & 100 & 31 & 24 \\
\hline Marburg & - & 89.94 & $47.7 \pm 0.5$ & 35 & 29 & 33 & 31 & 100 & 13 \\
\hline CB-12 & + & 88.82 & $47.4 \pm 0.4$ & 30 & 26 & 27 & 25 & 27 & 100 \\
\hline
\end{tabular}

${ }^{a} M$. thermoautotrophicum $\Delta \mathrm{H}^{\mathrm{T}}$ and Marburg, M. thermoformicicum Z-245, and Methanobacterium spp. strains CB-12, THF, and FTF.

${ }^{b}$ Homologous values are reported as $100 \%$.

1), and by Bezrukova et al. (3), who found that strain Z-245 is a serotype of $M$. thermoautotrophicum $\Delta \mathrm{H}^{\mathrm{T}}$.

The same grouping of the formate-utilizing strains was obtained by Nölling et al. (16), who studied plasmid contents and hybridization of total DNAs with the $f d h A$ gene from Methanobacterium formicicum JF. Furthermore, preliminary results (17) from a sequence analysis of the 16S rRNA genes from $M$. thermoformicicum strains and $M$. thermoautotrophicum $\Delta \mathrm{H}^{\mathrm{T}}$ and Marburg are in agreement with the results presented here but are in contrast with the findings of Yamamoto et al. (20), who proposed that the formateutilizing thermophilic methanobacteria should be separated into two groups on the basis of immunological cross-reactions with their antisera.

In our proposal a well-known and well-studied strain, $M$. thermoautotrophicum $\Delta \mathrm{H}^{\mathrm{T}}$, which has never been shown to grow on formate, is now included in a group that contains three formate-utilizing strains.

The inability to grow on formate may be explained by the fact that the genes for formate utilization are either not present or not functional. For $M$. thermoautotrophicum $\Delta \mathrm{H}^{\mathrm{T}}$ and Marburg the latter possibility seems to be the case since it has been shown recently by probing with the $M$. formicicum fdh operon (kindly provided by J. Ferry) that there are homologous sequences in the genomes of $M$. thermoautotrophicum $\Delta \mathrm{H}^{\mathrm{T}}$ and Marburg (15).

TABLE 4. Antigenic fingerprints of the strains analyzed and related reference methanogens

\begin{tabular}{|c|c|c|c|c|c|c|c|c|c|c|c|c|c|}
\hline \multirow{2}{*}{$\begin{array}{l}\text { Reference } \\
\text { strain }\end{array}$} & \multirow{2}{*}{$\begin{array}{l}\text { Test } \\
\text { strain }\end{array}$} & \multicolumn{12}{|c|}{ Reaction with S-probe ${ }^{a}$ : } \\
\hline & & 1 & 2 & 4 & 5 & 8 & 9 & 10 & 11 & 12 & 21 & 22 & 27 \\
\hline$\Delta H^{T}$ & & 0 & 0 & 1 & 0 & 0 & 0 & 0 & 2 & 4 & 0 & 0 & 1 \\
\hline \multirow[t]{5}{*}{ GC1 } & & 0 & 0 & 1 & 0 & 0 & 0 & 0 & 4 & 2 & 0 & 0 & 1 \\
\hline & $\mathrm{Z}-245$ & 0 & 0 & 0 & 0 & 0 & 0 & 0 & 3 & 2 & 0 & 0 & 0 \\
\hline & FTF & 0 & 0 & 0 & 0 & 0 & 0 & 0 & 3 & 3 & 0 & 0 & 0 \\
\hline & THF & 0 & 0 & 0 & 0 & 0 & 0 & 0 & 4 & 3 & 0 & 0 & 0 \\
\hline & CB-12 & 0 & 0 & 0 & 0 & 0 & 0 & 0 & 2 & 1 & 0 & 0 & 0 \\
\hline PS & & 4 & 0 & 0 & 0 & 0 & 0 & 4 & 0 & 0 & 0 & 0 & 0 \\
\hline \multirow[t]{2}{*}{ ALI } & & 3 & 0 & 0 & 0 & 0 & 0 & 4 & 0 & 0 & 0 & 0 & 0 \\
\hline & Marburg & 1 & 0 & 0 & 0 & 0 & 0 & 3 & 0 & 0 & 0 & 0 & 0 \\
\hline
\end{tabular}

$a$ The immunizing strains for the antisera were as follows: S-probe 1 , Methanobrevibacter smithii PS; S-probe 2, Methanobacterium formicicum MF; S-probe 4, Methanobacterium bryantii MoH; S-probe 5, Methanobacterium bryantii MoHG; S-probe 8, Methanobrevibacter ruminantium M1; S-probe 9, Methanobrevibacter arboriphilicus DH1; S-probe 10, Methanobrevibacter smithii ALI; S-probe 11, Methanobacterium thermoautotrophicum $\mathrm{GC1}$; S-probe 12, Methanobacterium thermoautotrophicum $\Delta \mathrm{H}^{\mathbf{T}}$; S-probe 21, Methanobrevibacter arboriphilicus AZ; S-probe 22, Methanobrevibacter arboriphilicus DC; and S-probe 27, Methanosphaera stadtmaniae MCB3. The intensities of the reactions ranged from 0 (no reaction) to 4 (maximum intensity).
It is obvious that a negative characteristic has limited taxonomic significance. Benstead et al. (2) have recently shown that a mesophilic Methanobacterium strain which was originally described as unable to utilize formate could be grown on formate under defined conditions. These authors indicated that "the ability to utilize formate is of limited taxonomical significance" in that case.

Therefore, we propose that the description of $M$. thermoautotrophicum should be modified in order to accomodate the formate-utilizing strains and that the name $M$. thermoformicicum should be rejected as a synonym of $M$. thermoautotrophicum. Strain $\Delta \mathrm{H}$ is maintained as the type strain, and strain Z-245 is included in the list of reference strains, whereas strain Marburg is removed from this list. An emended description of the species is given below. Further work will be needed to assess the correct positions of Methanobacterium sp. strains Marburg and CB-12; the present hybridization data indicate that these strains should not be classified in the species $M$. thermoautotrophicum. The idea that strains $\Delta \mathrm{H}^{\mathrm{T}}$ and Marburg should be placed in different species has been discussed by Brandis-Heep (5) and has been supported by Zeikus (21).

Emended description of Methanobacterium thermoautotrophicum (corrig.) Zeikus and Wolfe 1972, $712^{\mathrm{AL}}$. Methanobacterium thermoautotrophicum (ther.mo.au.to.tro.phi'cum. Gr. adj. thermos, hot; Gr. pref. auto, self; Gr. adj. trophikos, one who feeds; N.L. neut. adj. thermoautotrophicum, thermophilic and autotrophic) cells are slender, cylindrical, irregularly crooked rods that are 0.35 to $0.6 \mu \mathrm{m}$ wide and 3 to $7 \mu \mathrm{m}$ long and frequently occur in filaments that are 10 to $120 \mu \mathrm{m}$ long. Gram positive. Nonmotile. Endospores are not formed. Fimbriae are present.

Deep colonies in roll tubes are tannish white, roughly spherical, diffuse, and filamentous.

Growth is rapid in mineral medium with $\mathrm{CO}_{2}$ as the sole carbon source, $\mathrm{NH}_{3}$ as the sole nitrogen source, sulfide as the sole sulfur source, and $\mathrm{H}_{2}-\mathrm{CO}_{2}$ as the sole energy source. Growth on formate as the sole carbon and energy source is possible for some strains and is just as rapid as growth on $\mathrm{H}_{2}-\mathrm{CO}_{2}$. Not stimulated by organic additions, although acetate may be assimilated.

The $\mathrm{G}+\mathrm{C}$ content of the DNA is 48 to $50 \mathrm{~mol} \%$ (as determined by thermal denaturation). Some strains harbor plasmids.

Habitat: thermophilic, anaerobic digesters.

The type strain is strain $\Delta \mathrm{H}$ (= DSM $1053=$ ATCC 29096), which was isolated from an anaerobic sewage sludge digester; this strain does not grow on formate.

The reference strains include strains YTB (= DSM 1850) Zeikus et al. 1980 and Z-245 (= DSM 3720) Zhilina and Ilarionov 1984; the latter strain grows on formate. 
11

21

31

41

51

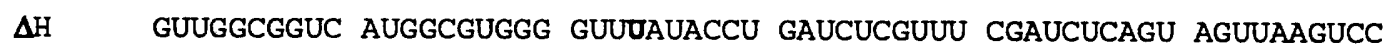

$Z-245$

$\boldsymbol{\lambda}$

\begin{tabular}{|c|c|c|c|c|c|c|c|}
\hline & 61 & 71 & 81 & 91 & 101 & 111 & 121 \\
\hline$\Delta \mathrm{H}$ & UGCUGCGUUG & UGGGUGUGUA & CUGCGGUUUU & UUGCUGUGGG & AAGCCCACUU & CACUGCCAGA & $\mathbf{C N} \mathbf{x}$ \\
\hline
\end{tabular}

FIG. 1. Alignment of 5S ribosomal RNA sequences from $M$. thermoautotrophicum $\Delta \mathbf{H}^{\mathrm{T}}$ and $M$. thermoformicicum Z-245. The sequences from the $5^{\prime}$ end to the $3^{\prime}$ end are shown. For strain Z-245 only the nucleotides that differ from the strain $\Delta \mathrm{H}^{\mathrm{T}}$ nucleotides are shown. Data from reference 6 .

\section{ACKNOWLEDGMENTS}

J.P.T. thanks D. Boone and S. H. Zinder for providing bacterial strains. J.P.T. is indebted to R. G. E. Murray for his encouragement and for help during this investigation and to P. A. D. Grimont and F. Gavini for their help with taxonomic methods and rules; he acknowledges the skillful technical assistance of F. Fontaine. A. J. L. Macario is acknowledged for his input into the antigenic fingerprinting work.

The immunologic work was supported in part by grant 7061ER BEA85 from GRI-NYSERDA-NY Gas to A. J. L. Macario and E.C.

\section{REFERENCES}

1. Balch, W. E., G. E. Fox, L. J. Magrum, C. R. Woese, and R. S. Wolfe. 1979. Methanogens: reevaluation of a unique biological group. Microbiol. Rev. 43:260-296.

2. Benstead, J., D. B. Archer, and D. Lloyd. 1991. Formate utilization by members of the genus Methanobacterium. Arch. Microbiol. 156:34-37.

3. Bezrukova, L. V., A. Y. Obraztsova, and T. N. Zhilina. 1989. Immunological studies on a group of methane-producing bacterial strains. Microbiology (Engl. Transl. Mikrobiologiya) 58:7783.

4. Brandis, A., R. K. Thauer, and K. O. Stetter. 1981. Relatedness of strains $\Delta \mathrm{H}$ and Marburg of Methanobacterium thermoautotrophicum. Zentralbl. Bakteriol. Parasitenkd. Infektionskr. Hyg. Abt. 1 Orig. Reihe C 1:311-317.

5. Brandis-Heep, A. 1981. Spezies-Characterizierung von Methanobacterium thermoautotrophicum (Marburg) und Desulfovibrio vulgaris (Marburg). Ph.D. thesis. Philipps-Universität Marburg/Lahn, Marburg, Germany.

6. Chumakov, K. M., T. N. Zhilina, I. S. Zvyagintseva, A. T. Tarasov, and G. A. Zavarzin. 1987. 5S RNA in archaebacteria. Zh. Obshch. Biol. 48:167-191. (In Russian.)

7. Ferragut, C., and H. Leclerc. 1976. Etude comparative des méthodes de détermination du Tm de l'ADN bactérien. Ann. Microbiol. (Paris) 127A:223-235.

8. Fuchs, G., E. Stupperich, and R. K. Thauer. 1978. Acetate assimilation and the synthesis of alanine, aspartate and glutamate in Methanobacterium thermoautotrophicum. Arch. Microbiol. 117:61-66.

8a.International Journal of Systematic Bacteriology. 1986. Validation of the publication of new names and new combinations previously effectively published outside the IJSB. List no. 21. Int. J. Syst. Bacteriol. 36:489.

9. Johnson, J. L. 1981. Genetic characterization, p. 450-472. In P. Gerhardt, R. G. E. Murray, R. N. Costilow, E. W. Nester, W. A. Wood, N. R. Krieg, and G. B. Phillips (ed.), Manual of methods for general bacteriology. American Society for Microbiology, Washington, D.C.

10. Macario, A. J. L., and E. Conway de Macario. 1983. Antigenic fingerprinting of methanogenic bacteria with polyclonal antibod- ies probes. Syst. Appl. Microbiol. 4:451-458.

11. Macario, A. J. L., and E. Conway de Macario. 1985. Antibodies for methanogenic biotechnology. Trends Biotechnol. 3:204-208.

12. Macario, A. J. L., and E. Conway de Macario. 1985. Monoclonal antibodies of predefined molecular specificity for identification and classification of methanogens and for probing their ecological niches, p. 213-247. In A. J. L. Macario and E. Conway de Macario (ed.), Monoclonal antibodies against bacteria, vol. 2. Academic Press, Inc., Orlando, Fla.

13. Maniatis, T., E. F. Fritsch, and J. Sambrook. 1982. Molecular cloning. A laboratory manual. Cold Spring Harbor Laboratory, Cold Spring Harbor, N.Y.

14. Mitchell, R. M., L. A. Loeblich, L. C. Klotz, and A. R. Loeblich III. 1979. DNA organization in Methanobacterium thermoautotrophicum. Science 204:1082-1084.

15. Nölling, J., and W. M. de Vos. Unpublished data.

16. Nölling, J., M. Frijlink, and W. M. de Vos. 1991. Isolation and characterization of plasmids from different strains of Methanobacterium thermoformicicum. J. Gen. Microbiol. 137:19811986.

17. Nölling, J., D. Hahn, K. H. Schleifer, and W. M. de Vos. Unpublished data.

18. Priest, F. G., M. Goodfellow, L. A. Shute, and R. C. W. Berkeley. 1987. Bacillus amyloliquefaciens sp. nov., nom. rev. Int. J. Syst. Bacteriol. 37:69-71.

19. Touzel, J. P., D. Petrofi, G. M. Maestrojuan, G. Prensier, and G. Albagnac. 1988. Isolation and characterization of a thermophilic Methanobacterium able to use formate, the strain FTF. Arch. Microbiol. 149:291-296.

20. Yamamoto, K., A. Tachibana, G. Dhavises, T. Tanaka, M. Takiguchi, and S. Oi. 1989. Characterization of a thermophilic formate-utilizing methanogen, Methanobacterium thermoformicicum strain SF-4. Agric. Biol. Chem. 53:533-534.

21. Zeikus, J. G. 1983. Metabolism of one-carbon compounds by chemotrophic anaerobes. Adv. Microb. Physiol. 38:215-297.

22. Zeikus, J. G., and R. S. Wolfe. 1972. Methanobacterium thermoautotrophicus sp. n., an anaerobic, autotrophic, extreme thermophile. J. Bacteriol. 109:707-713.

23. Zhao, Y., H. Zhang, D. Boone, and R. A. Mah. 1986. Isolation and characterization of a fast-growing, thermophilic Methanobacterium species. Appl. Environ. Microbiol. 52:1227-1229.

24. Zhilina, T. N., and S. A. Ilarionov. 1984. Isolation and comparative characteristics of methanogenic bacteria assimilating formate with the description of Methanobacterium thermoformicicum sp. nov. Mikrobiologiya 53:785-790.

25. Zhilina, T. N., and S. A. Ilarionov. 1985. Characteristics of formate-assimilating methane bacteria and description of Methanobacterium thermoformicicum sp. nov. Microbiology (Engl. Transl. Mikrobiologiya) 53:647-651.

26. Zinder, S. H., and M. Koch. 1984. Nonaceticlastic methanogenesis from acetate: acetate oxidation by a thermophilic syntrophic coculture. Arch. Microbiol. 138:263-272. 